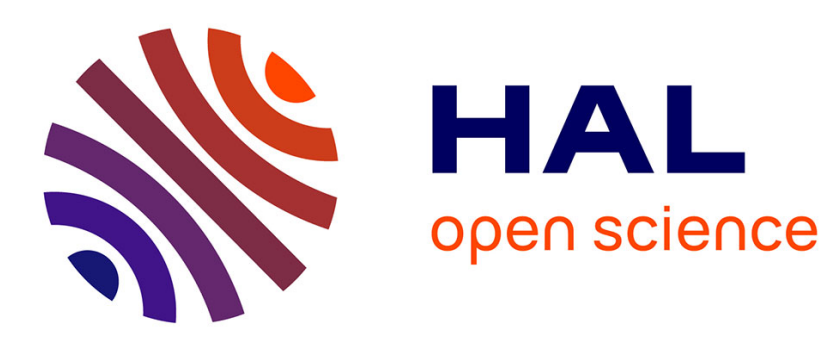

\title{
Russian aspect in finite and non-finite modes: from syntax to information structure
}

Eric Corre

\section{To cite this version:}

Eric Corre. Russian aspect in finite and non-finite modes: from syntax to information structure.

Sentence and Discourse, J. Guéron (ed.)., Oxford University Press, 2015. halshs-01474680

\section{HAL Id: halshs-01474680 \\ https://shs.hal.science/halshs-01474680}

Submitted on 23 Feb 2017

HAL is a multi-disciplinary open access archive for the deposit and dissemination of scientific research documents, whether they are published or not. The documents may come from teaching and research institutions in France or abroad, or from public or private research centers.
L'archive ouverte pluridisciplinaire HAL, est destinée au dépôt et à la diffusion de documents scientifiques de niveau recherche, publiés ou non, émanant des établissements d'enseignement et de recherche français ou étrangers, des laboratoires publics ou privés. 


\title{
Russian aspect in finite and non-finite modes: from syntax to information structure
}

\author{
Eric Corre
}

\author{
Université Sorbonne Nouvelle - Paris 3
}

This chapter investigates the use of perfective (PF) and imperfective (IMP) Russian verbs in both finite and non-finite modes, with special emphasis on the latter. As has often been observed in the aspectual literature, there are many counter-examples to the generalization in Smith $(1991,297)$ that the "the Perfective includes both endpoints of non-stative situations, while the Imperfective excludes endpoints". In (1a), the infinitive PF verb indicates a single (future) punctual event, but the answer in (1b) requires the use of the IMP corresponding verb for confirmation that the single punctual event took place ${ }^{1}$ :

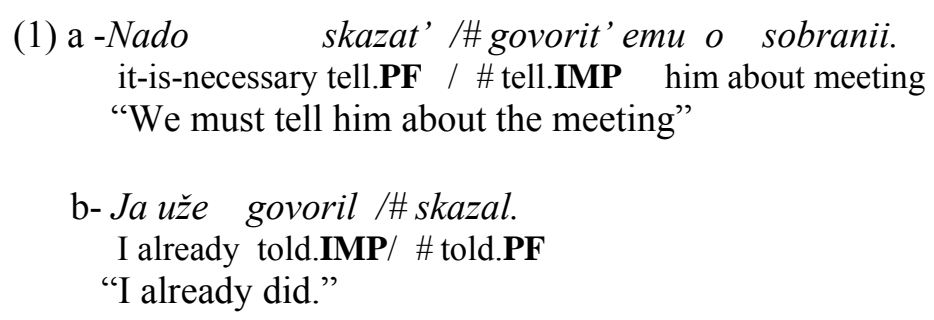

A similar asymmetry between finite and non-finite modes is found in (2). The universal adverb vsegda, 'always', is normally conjoined with an infinitive PF verb when following the modal predicate možet, 'can', as in (2a). The same sentence in the past tense in (2b) requires the IMP verb, however:

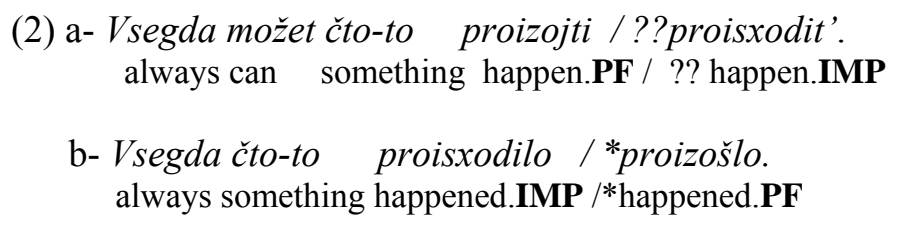

One needs to explain several phenomena concerning grammatical aspect: (i) PF verbs in the past tense can only denote single punctual events, whereas in the infinitive mode they can denote either a single or an iterated event. (ii) An IMP verb in the past tense can denote either an iterated or a punctual event. In view of this goal, the present chapter will make the following claims about Russian aspect:

First, viewpoint aspect (henceforth, VA; Smith 1991) is neutral in Russian; it is situation aspect (SA) that is grammaticized. More precisely, perfective morphology encodes telicity (albeit a revised version of it) while imperfective morphology merely encodes lack of telicity. Viewpoint aspect is arrived at via correlations. We adopt a model of sentence structure based on Borer (2005)'s exo-skeletal model of (neo-davidsonian) event structure. In this model, Russian prefixes are the overt exponents of a range assignment to an AspQ (i.e., aspect-asquantity) head, which corresponds to a functional node for telicity.

Second, we seek to account for the selection of an IMP or PF infinitival verb in cases like (1) and (2), which reveal an asymmetry between non-finite and finite modes. We will raise the question of telicity in non finite modes. In most cases, a PF infinitive indicates a brand-new

\footnotetext{
${ }^{1}$ The \# sign indicates that the IMP verbs govorit', "say" in (1a) and skazal, "told", in (1b) are not correct on the statement of fact interpretation.
} 
punctual (delimited) event. However, just as in the finite modes, IMP infinitives can also denote punctual delimited events. We will account for infinitival aspect in terms of discourse structure. In the following example, taken from a corpus of conversations on a radio talk show ${ }^{2}$, the IMP verbs in (3b) - stavit', "put"; menjat', "change"; sozdavat', "create" - are truth-conditionally equivalent to the PF verbs - postavit', "put"; izmenit', "change"; sozdat', "create" in (3a). The crucial difference is that the IMP verbs refer to already established topics that appeared earlier in the conversation:

\section{(3) a- Grečko - “Jest' različnye sposoby. Možno postavit' i tjagač, i tak dalee.” (...) it-is-possible put.PF also tractor, and so on Grechko : "There are several means. You can install a tractor, and so on. (...)}

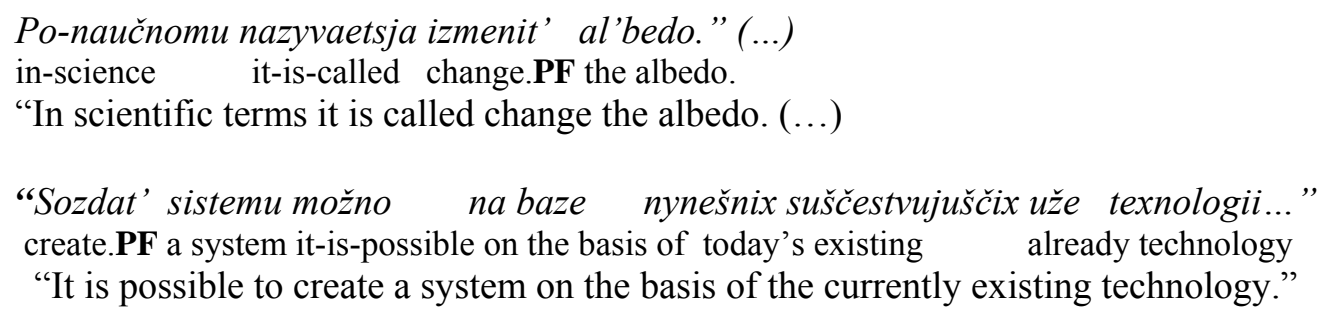

(3) b- E. Al'bac - "Ponjatno. Xorošo, èto vy mne potom rasskažete,čto za točki Lagranža. Stavit' tam teleskopy, oni dajut rannee opoveščenie ..."

put.IMP there telescopes...

E. Albac: "I understand. Good, you'll explain to me later what exactly is the Lagrange point. So, you said to install there telescopes, they'll give advanced warning...

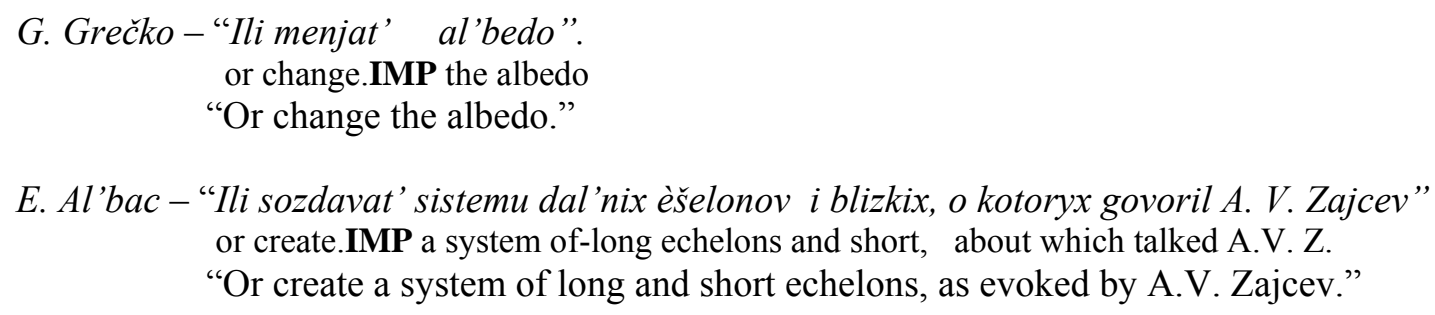

What needs to be explained is why an IMP verb can be used in discourse contexts in which a PF verb was previously used. The explanation turns on the hypothesis of a lack of a functional node for telicity and the consequent absence of Viewpoint Aspect for IMP verbs.

This chapter is organized as follows: Section 1 presents the principles of C. Smith's twocomponent theory of aspect. We claim that if one aims to provide a near exhaustive account of the aspect of verbs in Russian, then that approach must be augmented by pragmatic conventions of use or aspectual sub-meanings (Bondarko 1971's privatnye značenija, "particular senses"). The section examines some problematic cases that neither Smith's theory nor other theories account for satisfactorily. Section 2 develops the view, based on Borer (2005) and Lakorczyk (2010), that it is not VA but SA that is syntactically encoded in Russian. Section 3 seeks to explain why the use of aspects is different in non-finite modes from that in finite modes. It concludes by introducing a discourse-oriented account of aspect.

\footnotetext{
${ }^{2}$ The radio is Echo of Moscow, an opposition radio station. The data were collected between November 2013 and March 2013. The use of a corpus is motivated by the fact that discourse interactional parameters will constitute the core of the hypothesis defended here.
} 


\section{I- Traditional accounts of the aspectual opposition}

\section{I.1. Situation Aspect and Viewpoint Aspect}

Smith's account of the aspectual system owes much to the work of earlier Russian aspectologists such as Maslov (1948), Isačenko (1960), and Bondarko (1971), who established the distinction between modes of action (sposoby dejstvija, or Aktionsarten), and aspect (vid). Both belong to the larger category of aspektual'nost' ('aspectuality' or 'actionality'), which describes how the situation the verb phrase denotes is envisaged. For Smith, SA refers to the classification of "objective", i.e., lexically determined, situation types (Vendler 1957). VA, on the other hand, applies "subjectively" to situation types and focuses on either the internal structure or the endpoints of a situation. Aspect is thus described in a maximally general abstract way: the substantive basis of both SA and VA is the temporal structure of situations, including notions such as completion, totality, durativity, the existence of internal sub-situations, etc. (cf. Smith 1991: 23). The following English sentences illustrate the interaction of SA and VA:

(4) a. \#Mrs Ramsey wrote a letter, but she didn't get it written.

b. * Mrs. Ramsey wrote a letter, but she didn't finish writing it.

(5) a. Lily swam in the pond, but she didn't swim across it.

b. Lily swam in the pond, but she didn't finish swimming across it.

(Smith 1991:106-107)

In (4), write a letter is a telic situation type (a Vendler Accomplishment) in which the perfective viewpoint (henceforth, PFV) expressed by the simple past morpheme focuses on the inherent endpoint of the event. In (5), where swim in the pond is an atelic situation type (an Activity), the PFV says only that the event is no longer going on. From that perspective, imperfective viewpoint aspect (IMPV) is defined negatively: it focuses only a sub-stretch of the running time of the event. There are also derived situation types. According to Smith (1991: 84-87), nearly all situation types can be type-shifted and become either multiple-event activities or habituals. In Russian, these derived types are mainly expressed by IMP verbs (but there are notable exceptions in the infinitive, as we will see).

The theory also incorporates the idea that aspect is a parameter: the formal components of aspect (SA and VA) are realized differently across languages (Smith 1991: 22). Other authors, such as Tournadre (2001), have shown that the opposition of lexical SA and grammatical VA is not universal: an opposition that is realized lexically in one language can be expressed grammatically in another. Section two will defend a similar view. I claim that all twenty Russian prefixes ${ }^{3}$ are derivational morphemes, and they systematically turn an IMP bare verb into a PF verb, making it functionally telic. Smith also acknowledges that some meanings associated with a given PF or IMP verb do not pertain directly to the temporal structure of a situation (Smith 1991: 23), so that for a given language, one must learn the specifics of aspectual oppositions individually. Pragmatic considerations and conventions of use then come into play to "complement the semantic meanings" of the aspects (ibidem: 24).

\section{I.2. Conventions of use or "particular senses" (Bondarko 1971)}

\footnotetext{
${ }^{3}$ Verbal prefixes are called "preverbs" in the Slavistic tradition: they are originally adpositional elements amalgamated to the verb.
} 
One of the most daunting difficulties for the analysis of Russian aspect is the existence of many conventions of use attached to verbs of either aspect, some of which are not driven by strictly aspectual notions, that is, by the internal structure of the event. Russian aspectologists generally first present the most general features (priznaki) of the uses of PF and IMP verbs. Then, as in Bondarko (1971), they review different particular senses (častnye značenija) of sub-classes of verbs and contexts of use that are not predicted by the theory. Smith has a similar approach: after laying out the principles of her two-component, essentially semantic, account of aspect, she adds pragmatic, language-specific conventions of use to explain examples that do not conform to the theory.

No doubt the most puzzling feature of Russian aspect is that the conventions of use of an aspectual form differ according to the finite or non-finite mode of the verb. In particular, choice of viewpoint for infinitives differ from those defined for finite past forms in most accounts (cf. Vogeleer, this volume). Some examples were given in the introduction. Another classic example concerns the fact that the strong convention of "annulled result" or "two-way action" found in the IMP past with certain "reversible" verbs (open, bring, come, arrive, etc.) discussed in Forsyth (1970) is notoriously absent in the infinitive. For example, the IMP in (6a), on a punctual reading, means that the window was opened and subsequently closed. However, the infinitive IMP verb otkryvat' governed by the deontic modal nužno, "it is necessary", can not mean that "it's necessary to open and close the window". Rather, it receives either an iterated interpretation or it indicates that the time to carry out the action is imminent.

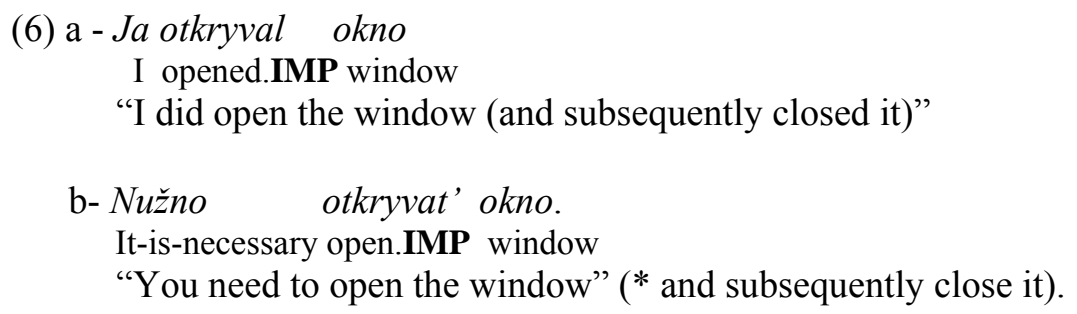

There is an "imminent passage to action" convention associated with the IMP verb in the infinitive but not in the finite past tense. According to Forsyth (1970), this convention is very frequent in the imperative and infinitive modes. It expresses "directness... urgency... [whereby] the speaker forcefully demands the immediate performance of the action [or expresses her] insistence on an immediate response (210-214). Our corpus (cf. note 2) contains many examples of this use of the IMP verb, such as ( $7 \mathrm{a}, \mathrm{b})$. In the past tense, these same IMP verbs would be understood as denoting progressive or repeated events, as in $(7 \mathrm{c}$, d), NOT as 'it was urgent for us to know / leave:

(7) a- Sootvestvenno, nado uznavat', kogda otkroetsja aèroport Vnukovo, Consequently it-is-necessary find.out.IMP when will-open airport Vnukovo dlja tex, kto uezžaet. for those who leave "Consequently, we've got to find out (as soon as possible) when Vnukovo airport will open, for those who are leaving".

b- $A$ jest' kakaja-to perspetktiva ili vsë-taki pora uezžat'? and there-is some perspective or really it-is-time leave.IMP

"And is there any perspective or is it urgent for people to just leave the country?"

c- Uznavali, $\quad$ kogda otkroetsja aèroport. they.find out.IMP.PST when will-open airport

"They were trying to find out when the airport will open" 


\author{
d- Oni uezžali \\ they.were.leaving.IMP.PST \\ "They were leaving" or "They (generally) left"
}

In the light of such asymmetries of use between finite and non-finite forms of the verb, it is difficult to maintain the abstract model of the two-component theory, based on the temporal structure of events as expressed by PF and IMP verbs. In the non-finite modes, the temporal structure of the event is in fact most often irrelevant. Note that Vogeleer (this volume) arrives at a similar conclusion with respect to the meaning alternation of the imperfective present tense (IMP-PR) and the imperfective past (IMP-PST) in complement clauses introduced by verbs of saying and/or cognitive factive verbs. Vogeleer shows that in the dialogue mode, with verbs of saying the alternation between IMP-PR and IMP-PST in complement clauses is governed by different temporal relations, while in the narrative mode, the alternation of these tense-aspect forms is mediated not by temporal relations, but by the information structure of the narrative. Such facts show that a revision of the two-component theory is needed.

\title{
II- VA is neutral, SA is grammaticized
}

Borer (2005)'s exo-skeletal model of the verb phrase is based on event structure. Borer contends that Aktionsart, and telicity in particular, is syntactically overtly encoded in Russian. Lakorczyk (2010), following Borer (2005), shows that preverbs in Polish are grammatical exponents of telicity, and that telicity is in turn instantiated syntactically through a quantity range assignment to an Asp head, AspQ (cf. Borer 2005 ,159). In Corre (2014, to appear), I propose that this quantity assignment is not strict quantization, which poses the existence of an incremental relation that maps part of an individual to part of an event. Rather, it is terminativity, a concept similar to (Depraetere 1995)'s boundedness (vs. telicity), and to a Boundedness Requirement (in Altshuler 2014): it is sufficient for a VP-event part to have culminated or not to have developed any further, to be perfective.

\section{II.1. Prefixes are quantity markers}

In (8c) below, the prefixed PF verb s'ela (buterbrod), "ate (a sandwich)" indicates that the event of eating the sandwich attained its completion point. This is a case of telicity cum quantization: the total consumption of the entity affected ensures that all of the event is over (Filip 2000, 2008). Not so in (8a) - a progressive event -, and in (8b) - a single event - where the IMP bare verb has only a retrospective meaning; the sentences are uncommitted as to the actual completion of the event. Note that in cases like (8b), where the event is terminated, English has to use the simple past or the pluperfect, just as in (8c) in which the event is telic (quantized). Nevertheless, the notion of telicity needs to be somewhat relaxed in the light of (8d) and (8e). In both sentences the verbs are morphologically PF; they are prefixed. Yet they are not quantized, taking either no object as in (8e), or an indefinite partitive object as in (8d). Note that they feature the use of the prefix po-, which is uncommitted as to the actual completion point of the event, but does indicate that is is terminated.

(8)

$$
\begin{aligned}
& \text { a- Poka on e-l buterbrod, za-zvoni-l telefon. } \\
& \text { while 3SG eat.IMP.PST.3SG sandwich, za-ring.PF.PST.3SG phone }
\end{aligned}
$$


"While he was eating the sandwich, the phone rang."

b- Ot zavtraka otkazalsja, - on uže el v devjat' utra.

from breakfast he-abstained.PF.PST, - 3SG already eat.IMP.PST.3SG at 9 of-the-morning

"He refused to get breakfast - he'd already eaten at 9 in the morning."

c- On s'-e-l buterbrod i lëg spat'.

3SG PREF.eat.PF.PST.3SG sandwich and go.PFV.PST.3SG to-bed

"He ate (finished eating) his sandwich and went to bed."

d-Zašël v kafé "Tradicija », gde poel blinov.

he-stopped by the-café " Tradition », where PREF.eat.PFV.PST pancakes.PART.

"He stopped by the café 'Tradition', where he ate some pancakes."

e- Nakormil sobaku, poel sam.

He-fed.PF.PST dog, PREF.eat.PF.PST himself

"He fed his dog, and had something to eat himself."

I concur with Borer and Lakorczyk that prefixation (preverbation), which in Russian is the overt exponent of perfective marking, "is a direct range assigner to an open value heading a functional category" (Borer 2005, 158). That functional category is the Asp head, which denotes "quantity", just like a quantized DP in English Accomplishment VPs such as John ate the sandwich. Still, data like (8d, e) have to be taken into account: contrary to (c), with the preverb " $s$-" and the quantization reading, sentences (d) and (e), with the preverb "po-", do not yield a quantized reading: they pose a "quantization puzzle" (Filip 2000). Such data raise the question of the exact nature of telicity.

II.2. What is telicity?

Telicity has been defined as the presence of an inherent enpoint (Vendler 1957, Dowty 1979), or in terms of event-argument homomorphism (Krifka 1998, Tenny 1994). However, as Borer (2005) notes, there are several types of telicity. The test of $i n-x$ time frame adverbials probes for a very particular type of telicity, one which marks the end of an event. Instead, she proposes that telic or Quantity predicates as she calls them, are predicates that are non homogeneous.

Homogeneity is defined by the properties cumulative and divisive. John read books is cumulative because "John read books" + "John read books" = "John read books". It is also divisive because "a part of 'John read books" = "John read books". Predicates that are both cumulative and divisive are atelic. Predicates that are not cumulative or divisive are telic. For example, John read three books is not cumulative ("John read 3 books" + "John read 3 books" = "John read 6 books" and "John read 6 books" is not in the denotation of the predicate "John read 3 books". Likewise, John read 3 books is not divisive: "a part of 'John read 3 books' is not "John read 3 books". The important property is that of divisiveness. A sentence like "John read many books" may not be divisive: "a part of 'John read many books' is not John read many books but John read a few books. For Borer, read many books exemplifies an intermediate culmination which is telic even though the quantity of books is indefinite so that the endpoint of the event remains vague ${ }^{4}$. For example, the English examples in (9) are telic:

$4 \quad$ For the details of the analysis see Borer (2005: 133-139). 
a- Kim ate more than enough meat.

b- We filled the room with smoke.

A predicate becomes telic at the point at which it becomes non homogeneous. In (9a), the point at which Kim ate enough meat $i$ s the endpoint. It is sufficient for there to be a quantity, which is either non divisive or non homogeneous for a telic reading of a predicate. One consequence of this line of reasoning is that the in x time adverbial test is epiphenomenal: it probes for telicity-as-finality. Other tests are needed. One test that does not only test finality and duration is the cumulativity test proposed by Lakorczyk (2010: 63): it consists in coordinating two time adverbials with a given predicate. A predicate that yields either a oneevent or a two-event interpretation is atelic, while a predicate that only yields a two-event interpretation is telic:

a- Kim ate meat on Monday and Tuesday (one or two events)

b- Kim ate 300 grams of meat on Monday and Tuesday (two events)

c- Kim ate more than enough meat on Monday and Tuesday (two events)

[examples adapted from Lakorczyk 2010:63]

(10a) is ambiguous: the sentence is felicitous if it describes either two episodes of eating meat distributed over two days, or two distinct episodes of eating meat on each day. But for (b) and (c), only the latter interpretation obtains: (b) cannot mean that part of the 300 grams of meat gets eaten on Monday, and the other part on Tuesday. Likewise, (c) does not entail that he ate enough meat on Monday and more than enough on Tuesday. Sentences (b) and (c) force us to understand that two distinct episodes of eating the specified quantity of meat occurred.

For Russian, IMP verbs systematically test as atelic. More importantly, the test helps to establish the fact that all PF verbs ${ }^{5}$ are telic. For example, a $z a$-verb, which is ingressive ("start doing something") tests as telic although it focuses only the beginning point of the event and lacks duration. Interestingly, $p o$ - verbs also test as telic:

$$
\begin{aligned}
& \text { a- On kuri-l v ponedel'nik } i \text { vo vtornik (1 or } 2 \text { events) } \\
& \text { 3SG smoke.IMP.PST.3SG on Monday and on Tuesday } \\
& \text { "He smoked on Monday and on Tuesday" } \\
& \text { b- On za-kuri-l v ponedel'nik } i \text { vo vtornik (2 events) } \\
& \text { 3SG za-smoke.PF.PST.3SG on Monday and on Tuesday } \\
& \text { "He lit up a cigarette on Monday and on Tuesday." } \\
& \text { c- On po-kuri-lr vonedel'nik } i \text { vo vtornik (2 events) } \\
& \text { 3SG po-smoke.PF.PST.3SG on Monday and on Tuesday } \\
& \text { "He smoked for a while on Monday and on Tuesday." }
\end{aligned}
$$

Only (11a), with the IMP verb, can mean that the smoking episodes can extend randomly over both days. The PF verbs in (b) and (c) imply that there were distinct episodes of smoking. Even (c), with delimitative po-, lexically encodes "the semantics of the end" in its meaning (Padučeva \& Pentus 2008: 209): "On pokuril" means "he smoked for a while and then stopped": it gives rise to two events. Only the IMP verb in (a), which is both cumulative and divisive, is atelic.

\footnotetext{
${ }^{5}$ For discussion on the different types of PF verbs in the Russian literature, see Corre (2014, to appear).
} 
In Corre (2014), I propose that the concept of terminativity is the most appropriate for describing the semantics of Russian prefixed PF verbs. As Padučeva \& Pentus (2008) and Mehlig (2008) note, all prefixed PF verbs have the "semantics of the end lexically encoded in their meaning" (ibid.). Crucially, however, terminativity need not cover the whole interval; it is not synonymous with quantized. The difference it allows between "absolute-terminative and relative-terminative predications" (Mehlig 2008: 258) is best observed by comparing different PF verbs for a single IMP root (a procedure often neglected in the literature). Consider the following examples with the bare IMP verb stirat', "wash":

a- Gde moj zelënyj sviter? Ja xocu idti v nëm v magazin.

"Where's my green sweater? I want to wear it to go to the store."

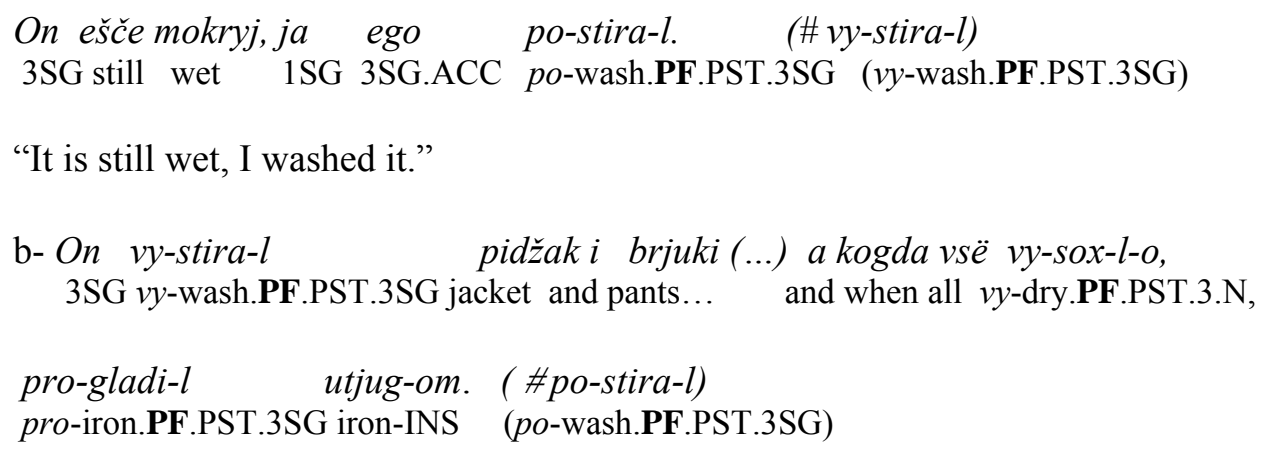

"He washed his jacket and pants (...), and when everything had dried off, ironed all of these." http://www.ruscorpora.ru/search-main.html\#)

Although the sentence with $p o$ - is felt to be less resultative than the one with the preverb vy, it is nevertheless telic. It means that some washing was completed on the sweater, without specification of the final state of cleanliness of the entity. As Jablonska (2004) says of po- in Polish: it "introduces an arbitrary Reference Time that seals off the event." (367)

The preceding sections have shown that if the notion of telicity is revised so that finality as measured by the in-x-time test is just one case among others, then all preverbs, which morphologically perfectivize an IMP root in Russian, can be considered as telic. A more adequate notion is terminativity (Padučeva \& Pentus 2008, Mehlig 2008), understood as a functional operation whereby a preverb added to an atelic IMP root encodes a semantics which necessarily seals off the event. In contrast, an IMP verb in the past may or may not indicate termination. This generalization is supported by the overwhelming empirical fact that adding a preverb in Russian automatically makes an IMP root terminative.

Before turning to the behavior of aspect in the infinitive, let us examine the consequences for the grammar of the functional role of prefixal marking in Russian.

\section{II.3. SA is grammaticized, VA is neutral}

I arrive at the same conclusion as Lakorczyk (2010): "Viewpoint aspect in languages such as Polish and Russian is marked by zero morphology."(90). VA is expressed in Russian by means of correlations or compositional restrictions such as the following:

\begin{tabular}{|c|c|c|}
\hline Morphology of verb: & Situation type: & Viewpoint type: \\
\hline Base IMP verb & atelic & PFV or IMPV \\
\hline
\end{tabular}


Examples (1b) and (8b) show that a bare IMP verb in the past tense denotes an atelic eventuality which receives either a PFV or an IMPV reading. We conclude, therefore, that perfective and imperfective morphology do not have the function of marking viewpoint aspect, contrary to Smith (1991) and Zucchi (1999). Two important facts support this view:

1) preverbs are found in forms that need not have a PF interpretation, namely, secondary imperfective (SI) forms. Secondary imperfectives behave exactly as bare IMP: they may have IMPV as well as PFV. In the following examples, the SI verb zakazyval, "order", can denote either a progressive (13a) or else a bounded (13b) event:

(13)

$$
\begin{aligned}
& \text { a- Kogda ja pri-së-l, oni za-kaz-yva-l-i} \quad \text { bljuda. } \\
& \text { When 1SG pri-go.PF.PST.1SGarrived 3PL za-order-2.IMP.PST.3PL dishes.ACC } \\
& \text { "When I arrived, they were ordering the food." }
\end{aligned}
$$

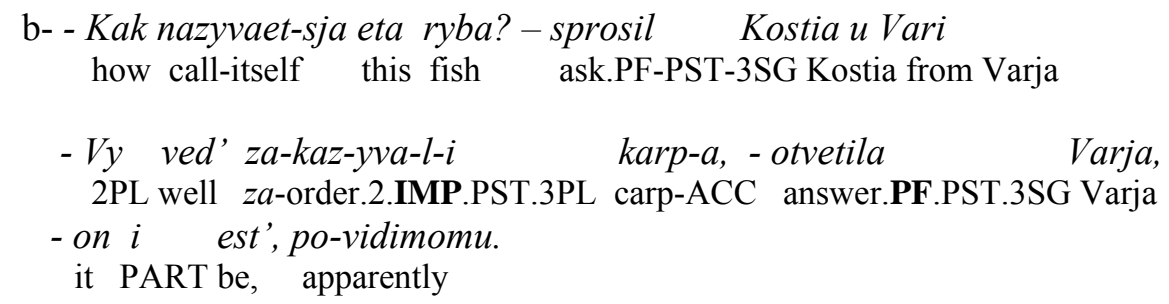

"What's the name of that fish?" - Kosti asked Varia.

"Well, you ordered a carp, didn't you? - answered Varia. "That's what it is, obviously."

(13b) illustrates a very frequent use of IMP verbs in conversation, in which the addressee is reminded by the speaker of a fact that she should have been aware of. Forsyth (1970) calls it the "statement of fact" convention. Here, the SI suffix -yva is not a marker of IMPV; rather, it behaves like a bare IMP and can be temporally unbounded as well as bounded. I thus concur with Lakorcyk (2010) in analyzing the SI suffix as an atelicizer, which simply undoes the telicity of the preverb. Crucially, it is not an IMPV progressive operator.

2) Further confirmation that PF verbs need not mark perfective viewpoint comes from the behavior of eventive nominalisations. In (14a) and (b), the nominals derived from SI denote atelic processes, not results; nor do they introduce any temporal effects which would suggest a progressive VA interpretation:

za-pis-yva-nie zvuk-ov na plastink-e

$z a$-write-2.IMP.NMLZ sound-GEN.PL on record.LOC.SG

"the registration of sounds on a record"

po-kaz-yva-nie kartin-ok

po-show-2.IMP.NMLZ painting-GEN.PL

"the showing/display of paintings."

Further evidence of the absence of temporal interpretation (i.e., VA) linked to the use of PF or IMP verbs is found in the infinitival examples (3b) and (7a,b) above. In these sentences, 
IMP verbs are not used to focus the inner part of the process but are truth-conditionally equivalent to a $\mathrm{PF}$ verb.

Our discussion so far begs a question: if VA is not grammatically marked in Russian, how do we account for the systematic alternation of the aspects in infinitives? This, we claim, is where discourse notions come into play.

\section{III- From syntax to discourse: the case of infinitives}

Let us recapitulate our core hypothesis. We have established that a PF verb, morphologically made up of the complex "preverb + IMP bare verb + past tense morpheme $l$ " unambiguously denotes a single closed-off event. This is the result of the telic-terminative function of perfective morphology in Russian: for past tense predicates, an event inclusive of bounds arises unambiguously for prefixed PF verbs as result of the combination of the AspQ telic head and the tense morpheme, indicating existential closure. A PF verb in the past is predicted to always have a perfective viewpoint ${ }^{6}$. This is not the case for an IMP bare verb or a SI verb, for which the crucial functional property is lack of telicity. Recall that in Borer's model, atelicity is not projected: it arises in the absence of a telicity-marking AspQ head. Thus an IMP verb in the past is predicted to give rise either to a single closed-off, but not telic (PFV) event, or else to an IMPV open (progressive, multiple) eventuality.

Our account, which assigns to telicity/terminativity a functional role for which the overt exponent is prefixal morphology, and claims that IMP morphology is simply the absence of that functional role, seems superior to those that endow the PF and IMP verbs with viewpoint aspect. In particular, it helps to explain why these same properties carry over naturally to infinitives.

- A PF infinitive always denotes an event inclusive of bounds, with a strong (but not exclusive) tendency toward a single event interpretation. When embedded under an IMP matrix tensed verb, as in (2a), it yields what the literature has called the "vivid-illustrative use": a single token of the event is taken as a model for repetition. We will show, furthermore, that in many cases, use of an infinitive PF verb is highly favored in types of discourse in which an event is single and brand-new within a conversational interaction.

- IMP infinitives, as predicted, denote an eventuality irrespective of the existence of bounds. First, they are obligatory when no bounds are induced, in particular with aspectual verbs and in explicit iterative generalizing contexts. Second, in contrast with PF verbs, they are used in discourse contexts in which the eventuality is not new but is rather already topical in the interaction.

The challenge now is to uncover the mechanism which allows PF and IMP verbs to receive distinct discourse interpretations. I begin by discussing corpus results concerning the behavior of infinitives.

III.1. Corpus results.

$6 \quad$ This punctual single-event interpretation for past PF verbs does not arise for present-future PF verbs. There are well-known examples in the literature in which a PF verb conjugated in the "present-future" tense embedded under the iterative particle byvalo has a past iterative interpretation.

Inogda byvalo, obgonit kto na dejstvitel'no xorošej mašine.

sometimes it-used-to-be, overtake.PF.FUT.3SG someone in a.really good car

"Sometimes he'd be overtaken by a really fast car." 
Except for aspect, the syntax of the infinitive in Russian is roughly similar to that in English or French: an infinitive VP can be the complement of aspectual predicates (begin, stop), modal expressions (it is necessary, one must, it is possible, it is advisable, etc...), desiderative and manipulative predicates (want, ask, allow, forbid, try, offer, etc.). There are also language-specific constraints: certain introductory predicates may require the use of either a PF or an IMP verb. Among these are:

1) the obligatory use of IMP with certain "subjective" matrix predicates, i.e., expressions indicating the futility, undesirability or irrelevance of considering a particular action. This goes with the very strong tendency of IMP verbs to occur after negation.

2) the obligatory use of IMP with all aspectual predicates (begin, stop, finish, continue), and after the auxiliary byt' conjugated in the future, to yield the iterated future.

3) the obligatory use of PF with certain predicates that emphasize that the single event successfully occurred.

True cases of aspectual choice are found in the rest of the cases. They will be the focus of what follows.

The corpus indicated in note 2 contains 37827 words, which represent about 5:30 hours of radio show. The language is both semi-formal and spontaneous: the radio host provides a theme for the discussion, but the conversation often deviates and there is a great deal of improvisation. The themes are topical: they include the recent law forbidding adoption of Russian orphans for foreigners, the fall of meteorites on Siberia, presentation of the show's programme for the upcoming year, the corrupt judiciary system, the fate of the opposition, etc. Spontaneity is attested by the use of many discourse markers (vot, nu, ved'...), repetitions, hesitations, re-phrasings, etc. Each instance of an infinitival IMP or PF verb was counted. Table 1 gives the number of tokens for each category:

\begin{tabular}{|l|l|l|l|}
\hline corpus & Number of words & $\begin{array}{l}\text { Number of IMP } \\
\text { infinitive verbs }\end{array}$ & $\begin{array}{l}\text { Number of PF } \\
\text { infinitive verbs }\end{array}$ \\
\hline 1 & 3934 & 51 & 31 \\
\hline 2 & 4284 & 88 & 58 \\
\hline 3 & 5757 & 83 & 54 \\
\hline 4 & 6572 & 107 & 98 \\
\hline 5 & 6478 & 90 & 55 \\
\hline 6 & 5127 & 70 & 90 \\
\hline 7 & 5695 & 54 & 55 \\
\hline ALL 7 corpora & 37827 & 543 & 441 \\
\hline
\end{tabular}

Table 1: rough numbers of tokens of IMP and PF verbs

Each occurrence was classified according to the meaning expressed in the given context on the basis of sub-meanings and conventions of use described in the literature (see section II). Some sub-meanings were lumped together: for example, generic, habitual, and iterated uses of IMP verbs (Table 2,1) were placed in one category, as they represent similar "derived types" in Smith's terms. The periphrastic future using auxiliary byt' (Table 2, 2.) followed by an IMP verb also expresses iteration and repetition, yet these occurrences were counted separately because the IMP is an obligatory choice here. In the preceding category, the infinitive PF verbs can also express potential or actual repetition of an event. That is one of its "vivid-illustrative uses" (Forsyth 1970) along with its use with modal expressions of possibility (možno, vozmožno). These uses were counted together because they often describe events with similar truth-conditions, that is, events that are presented as unique but which have a potential for repetition. This particular case of competition between PF and IMP verbs, 
when both forms can express iteration, is one of the thorniest issues raised by aspect in the infinitive mode. It will be discussed below.

Note that the low percentage of predicates in our examples which obligatorily trigger the use of an IMP infinitive (aspectual verbs: 7.9\% - Table 2, 5.), and the even lower proportion of predicates which demand a PF verb (mainly those denoting the success of an undertaking: $6.34 \%$ - Table 3,3 .) are easily explained by the fact that such cases are simply rare in actual conversation. The overall majority of occurrences involve a real competition between IMP and PF verbs.

Tables 2 and 3 recapitulate the submeanings represented in all 984 (543 IMP $+441 \mathrm{PF})$ occurrences of infinitive PF and IMP verbs identified. The last row contains the number of truly puzzling uses in the sense that they do not conform to the other sub-meanings. Each table is followed by illustrative examples:

\begin{tabular}{|l|l|l|}
\hline $\begin{array}{l}\text { Submeaning/convention of use of } \\
\text { infinitive IMP verb }\end{array}$ & $\begin{array}{l}\text { Number of occurrences (out of } \\
543 \text { across all 7 corpora) }\end{array}$ & $\begin{array}{l}\text { \% of the number of overall } \\
\text { tokens }\end{array}$ \\
\hline 1. Generic/iterated/habitual situation & 98 & 18.04 \\
\hline $\begin{array}{l}\text { 2. With future auxiliary byt' (budu, } \\
\text { budem, budet...) }\end{array}$ & 109 & 20.07 \\
\hline $\begin{array}{l}\text { 3. Durative, event in progress or } \\
\text { contemporaneous to utterance context }\end{array}$ & 53 & 9,76 \\
\hline $\begin{array}{l}\text { 4. With negation or negative } \\
\text { expression }\end{array}$ & 60 & 11.04 \\
\hline 5. With aspectual verb & 43 & 7.91 \\
\hline $\begin{array}{l}\text { 6. bi-aspectual verbs and imperfectiva } \\
\text { tantum (i.e., verbs having both aspects } \\
\text { or existing only in the IMP) }\end{array}$ & 86 & 15.83 \\
\hline 7. Imminent passage to action & 48 & 8.83 \\
\hline unexpected uses & $\mathbf{2 7}$ & $\mathbf{4 . 9 7}$ \\
\hline
\end{tabular}

Table 2: statistics for infinitive IMP verbs

(14) Example of IMP verbs corresponding to the sub-meanings in Table 2

1. Vot takuju programmu s uslovnym nazvanijem 'Arsenal' my planiruem zapuskat' so such program with conventional name Arsenal we plan.to broadcast.IMP po ponedel'nikam, 22 časa.

on Mondays at.22 hours

"So, this programme which goes by the conventional name of 'Arsenal' we plan to broadcast every Monday at 10.PM"

2. I budem priglašat' $k$ sotrudničestvu blogerov, $i \quad$ našix slušatelej, $i$ členov $\quad k l u b a$ and we.will invite.IMP for cooperation bloggers and our listeners and members of.club russkojazyčnyx.

of.Russian speakers

"And to cooperate with us, we will be inviting bloggers, our listeners and members of the clubs of Russian speakers as well."

3. Počemu kislotoj ? Potomu čto bit' dolgo.

why with.acid ? because to.beat.IMP long.time

"Why did they use acid? Because it would have taken to long to beat him up!"

Žalko vas preryvat', no na 'Exe' novosti.

too.bad you interrupt.IMP, but on 'Echo' the.news

"I'm sorry to be interrupting you, but the news is coming up on 'Echo",. 
4. Ona ne sobiraetsja ničego menjat' v političeskom sisteme.

she not intends nothing change.IMP in political system

"She doesn't intend to change anything in the political system."

5. Načali xodit' po Moskve sluxi. began.to walk.IMP across Moskow rumor.

"The rumor started to spread around Moscow."

6. Čislo želajuščix èmigrirovat' bylo men'še. number of.wishing to.emigrate.IMP was less

"The number of people wishing to emigrate was less."

7. Nam uže zakančivat' nado. to-us already finish.IMP it.is.necessary

"We've got to finish right now."

The following table presents the numbers for PF verbs:

\begin{tabular}{|l|l|l|}
\hline $\begin{array}{l}\text { Submeaning/convention of use } \\
\text { of infinitive PF verb }\end{array}$ & $\begin{array}{l}\text { Number of occurrences (out of } \\
441 \text { across all 7 corpora) }\end{array}$ & \% of given submeaning \\
\hline $\begin{array}{l}\text { 1.Specific/punctual/unique } \\
\text { situation }\end{array}$ & 225 & 51.02 \\
\hline $\begin{array}{l}\text { 2. Vivid-illustrative use / with } \\
\text { modals expression of possibility } \\
\text { (možno/vozmožno, "it is possible") } \\
\text { - repeated situations }\end{array}$ & 140 & 31.74 \\
\hline $\begin{array}{l}\text { 3. With obligatory PF } \\
\text { predicates (udat'sja, "succeed", } \\
\text { uspet' 'have time to", smog, "was } \\
\text { able to") }\end{array}$ & 28 & 6.34 \\
\hline $\begin{array}{l}\text { 4. With negation of logical } \\
\text { impossibility (ne PF) }\end{array}$ & 37 & 8.39 \\
\hline unexpected uses & $\mathbf{8}$ & $\mathbf{1 . 8 1}$ \\
\hline
\end{tabular}

Table 3: statistics for infinitive PF verbs

(15) Example of PF verbs corresponding to the sub-meanings in Table 3:

1. Bojus' rasstroit' opjat'svoim ne-patriotizmom ...

I'm.afraid.to discourage.PF again with.my no-patriotism

"I'm afraid to discourage everyone again with my absence of patriotism."

Rodnoe pravitel'stvo poprosilo ix vyručit' staršuju sestru. native government asked them to.help.out.PF elder sister.

"The big brother government asked them to help out the elder sister."

2. Eto suženie ix vozmožnostej najti papu, mamu, najti semju. it.is reduction of.their.possibilities to.find.PF a.daddy, a.mummy to.find.PF a.family

"It reduces their possibility of finding a daddy, a mummy, of finding a family."

3. Ne udalos' podojti $k$ Vladimiru Vladimiroviču. not it.succeeded get.near. PF Vladimir Vladimirovich

"I did not manage to get near Vladimir Vladimirovich [Putin]."

4. Ja pokupal džinsy vSŠA prosto potomu, čto ix nel'zja bylo kupit' v Moskve. I bought.IMP jeans in USA only because them impossible was to.buy. PF in Moscow 
"I bought jeans in the US because it was simply impossible to buy them in Moscow."

\section{III.2. Commentary}

Observation of the results confirms the analysis presented above: the vast majority of IMP verbs in the infinitive denote atelic eventualities: durative $(10 \%)$, exclusive of bounds with aspectual verbs $(8 \%)$, with the future auxiliary byt' denoting progressive or iterated eventualities $(20 \%)$. The IMP is also strongly preferred for the denotation of generalizing eventualities (iterative, habitual) - 18\%. The truly unexpected uses (in boldface in Tables 2 and 3 ) account for only $5 \%$ of the cases, a very small proportion.

Likewise, PF infinitive verbs are used overwhelmingly in telic-terminative situations: with verbs of success for a single event $(6,5 \%)$, with single, specific situations $(51 \%)$, with socalled vivid-illustrative uses (32\%). Again, the truly unexpected uses account for only $2 \%$ of the cases.

The competition between the vivid-illustrative use of PF infinitives and the (normal) generic use of IMP verbs has received a lot of attention in the slavistic literature. Both forms of the verb can refer to repeated events. What is surprising is the ability of the PF verb to denote multiple events. According to Bondarko (1971) and Maslov (1972), the IMP denotes unlimited multiple events (neograničenno-kratnoe) whereas the PF expresses vividillustrative events with a potential for repetition (nagljadno-primernoe značenie). For Maslov, the unlimited multiple IMP is a central use of the IMP verb, one of the hallmarks of imperfectivity, but the vivid-illustrative use of the PF falls under the category of what he calls "synonymy of the aspects and peripheral uses". Our corpus study reveals, however, that this use is not peripheral: $31,7 \%$ of the PF infinitives in the corpus refer to potential generic/repeated events. Typical minimal pairs are the following:

(16) To jest' každyj dlja sebja, i tut uvy, net, universal'nogo recepta. Každyj dolžen dlja each.one must for

sebja prinjat' rešenie.

himself make.PF a.decision

"That is, every man for himself, and alas, here there's no universal recipe. Each one of us has to make our own decision.

(17) Oni načinajut dumat' o tom, čto oni voobšče-to ne skot. Oni xotjat prinimat' kakie-to they want to.make.IMP some

rešenija v svoej strane.

decisions in their country

"They start thinking that they should not be treated as cattle. They want to make decisions in their own country."

No special mechanism is necessary to account for these cases; they follow naturally from the account presented above. The PF expresses a subject's potential to perform a particular single action, but it is presented as a generalized fact, that is, given as an example (note the use of the singular form of the accusative NP in (16). The generic action is "particularized" (Maslov 1972); it is presented as a concrete, terminative fact that applies to all individuals. In contrast, by using an IMP verb as in (17), the speaker presents the action in its generality as applying to all subjects right from the start (note the use of a plural object in (17)). This use of the PF verb has become so conventionalized that it frequently appears in conjunction with an overt iterative adverb (periodičeski, "periodically'; v ljuboj moment, "at any time"), as in (18) and (19). 
(18) No u babuški voznikajut problemy, ej periodičeski nužno leč' v bol'nicu, to.her periodically it.is. necessary .lie.PF in hospital

ej nužno prosto uexat'.

to.her it.is.necessary simply go away.PF

"But the grandmother starts to have health problems, she has to lie in hospital periodically, she simply has to leave home."

(19) Ego možno v v ljuboj moment obobrat', unizit', otobrat' mašinu. him it.is.possible at any time rob. PF humiliate. PF take away.PF car

$i$ esli on vyskazyvaet vozmuščenie, ešče na 2 goda posadit' and if he expresses annoyance more for two years put.in.jail.PF

"At any time they can rob or humiliate him, take away his car. And if he expresses annoyance, he can be put in jail for two more years."

There remain truly puzzling cases, however. Consider the following dialogue, in which the discussion revolves around possible strategies to avert future meteorite rainfalls. One possibility is to launch a cloud that would cause the meteorites to veer off course:

(20) Al'bac - "Ved' nikto ne mog predskazat',čto meteorit priletit k Čeljabinsku. Vy že ne možete you PART. cannot

zapuskat' oblako $i$ ubirat'.",

launch.IMP the.cloud and go.away.IMP

"Well, no one could predict that the meteorite would fly to Cheliabinsk. For sure you cannot

launch the cloud and go away..."

Grečko - "Oblako možno tol'ko navstreču zapustit', kogda ty našël..." a.cloud it.is.possible only towards.it launch.PF, when you've found...

"You can only launch the cloud towards the meteorite when you've found it..."

In (20), the first IMP verb occurs after a discussion of experiments led by American astronomers in the 1960s to divert the course of an asteroid using a cloud of needles. The possibility of launching a cloud (zapuskat' oblako) has already been at the center of the discussion. We hypothesize that the IMP verb surfaces here because for both speaker and hearer, there exists a consensus that there is an "objectively" repeated/iterated situation. However, the second speaker judges that a generalization is not possible at this point because launching a cloud can be effective only under certain conditions; hence the use of the PF verb (zapustit' oblako).

Russian aspectologists have already observed that the competition between PF and IMP verbs for generalized events are "contextually or situationally linked ...; the context is a full partner of aspectual forms, and together with them it determines features of the action which are communicatively significant" (Maslov 1972,108; my emphasis). Following the work of Nuyts (2012) on (inter)subjectivity in modal evaluations, I argue that even conventionalized meanings are regulated by interactional dynamism. In (24), the occurrence of the PF verb in speaker B (Grechko)'s reply constitutes a conversational "reaction" to the previous IMP verb in speaker A (Albac)'s utterance. What is at stake is not whether the event denoted is single or multiple, but the actual communicative circumstances, the position of the interlocutors in the conversational interaction. At this point in the conversation, has the speaker said all that needed to be said about a given situation for the hearer to make sense of it, and possibly to move to a new subject, or does she need to say more? The problem is not simply the 
discourse-new vs. discourse-old feature of PF or IMP verbs. The situation expressed by a given predicate can be discourse-old, that is, already evoked, and yet be PF, as we have seen. In (20), speaker B deems it necessary to use the PF verb zapustit' because he realizes that speaker A considers (wrongly) that the matter is settled: speaker B needs to re-activate the topic. The choice of the IMP or PF verb is an important element in negotiating the mutual positions of the interlocutors in the conversational interaction. With the IMP verb, the possibility of launching the cloud can be established as a conversational consensus for speaker A (a settled topic), but this is not the case for speaker B, as is conversationally signalled by the use of the PF verb.

The challenge is now to show how this fits in the syntactic account of aspects presented above.

\section{III.3. Syntactic structure and discourse interaction}

Can one show that the principles of discourse grammar that have just been suggested are not mere pragmatic additions to interpretation but are already active in syntax? I suggest that the syntax of PF and IMP verbs may account for their contribution to the discourse interpretations observed here. The suggestion is difficult to implement because the type of discourse situation I have introduced is interactional; that is, it evolves simultaneously with the changing positions of the interlocutors.

In other words, we want to show how a PF infinitive verb encoding a functional projection identified as a telicity/terminativity head (AspQ) can ensure both that the event is single/unique/completed or terminated, AND that it is discourse-interactionally new in the sense proposed above. A syntactic execution of this goal would proceed as follows: on a higher level of syntax, say, on the split-CP, a PF telic VP is raised to a Focus head. According to Rizzi (1997), focus is a quantificational (operator-variable structure). Let us take example (20) as an illustration:

(20) Oblako možno tol'ko navstreču zapustit', kogda ty našël... a.cloud it.is.possible only towards.it launch.PF, when you've found...

For Rizzi, the quantificational nature of Focus is that the "meaning of a sentence requires evaluation at different values": in (20), the focus is the variable "what circumstances make it true that the cloud can be launched?"; PF-zapustit' oblako is an open choice; it calls the previously established topic (IMP-zapuskat' oblako) into question. This analysis finds support in observations often made in the literature, viz. that in the "PF verb + object complex", (here, zapustit' + oblako), the two entitities are intonationally (and, here, syntactically) two separate entities (Forsyth 1970, Veyrenc 1980). The analysis is also supported by pragmatic accounts of foci (Lambrecht 1992); namely, that the focus contains propositional content not predictable from previous interactions; it expresses what the speaker believes the addressee can not guess prior to hearing the utterance.

For Rizzi, a topic, on the other hand, is a constant, not a quantificational element. In example (20), for example, at the point of interaction, the launching of clouds is the established topic, accepted as a constant in conversation. Note that intonationally, the IMP verb + object (zapuskat'oblako) forms a single unit, as noted by (Forsyth 1970, Veyrenc $1980)^{7}$.

\footnotetext{
${ }^{7}$ [In the case of an IMP verb,] verb and object coalesce into one unit of meaning having one main stress, but this whole grammatical predicate is itself relatively unstressed (...), [the object in the imperfective sequence $\mathrm{V}+\mathrm{O}$ ] becomes a generalised complement of the verb rather than a semantically weighted reference to a specific real object acted upon." (Forsyth 1970: 84; 89)
} 
(20) Vy že ne možete zapuskat' oblako i ubirat'

you PART. cannot launch.IMP the.cloud and go.away.IMP

This is in fact what happens in most cases of the puzzling uses; (21) is the repetition of (3) above:

(21)
- Stavit' tam teleskopy, put.IMP there telescopes...
"to install there telescopes"
- Ili menjat' al'bedo. or change.IMP the albedo
"Or change the albedo."
- Ili sozdavat' sistemu dal'nix èšelonov i blizkix or create.IMP a system of-long echelons and short
"Or create a system of long and short echelons

At this point in the conversation, the VPs have been raised to a topic position: they get a fixed value from the context; they are not even embedded under a matrix verb. In earlier versions of these same VPs, however the denotata of the PF verbs were truly open possibilities, variables in the Rizzi sense, hence foci:

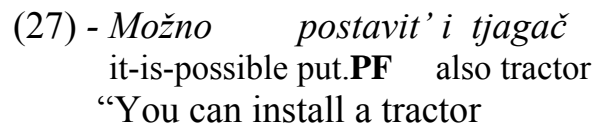

- Po-naučnomu nazyvaetsja izmenit' al'bedo.” (...)
in-science it-is-called change.PF the albedo.
"In scientific terms it is called change the albedo. (...)
- Sozdat' sistemu možno na baze nynešnix suščestvujuščix uže texnologii
create.PF a system it-is-possible on the basis of today's existing already technology
"It is possible to create a system on the basis of the currently existing technology."

The mechanism described above relies crucially on conversational interaction, in particular on the knowledge state of each participant in the exchange, rather than on the discourse-new $v s$. discourse-old character of the states of affairs. This account accords well with Asher's observation (this volume) that "an important aspect of language and linguistic usage is not directly related to truth conditional content but to relationships of power between conversational participants" (my emphasis). Asher calls this level "rhetorical cooperativity". Applied to our current observations, we might propose that a speaker either validates an event or proposition as topical (IMP verb) or she does not yet do so (PF verb). I suggest that this principle is already active in syntax: functional telicity attached to a PF verb makes it a likely candidate for focus under a split-CP, while lack of functional telicity (i.e. atelicity) makes a VP a suitable candidate for topic, a confirmed statement with past tense, a confirmed topic in the infinitive. Lack of telicity for the IMP verb acts negatively, so to speak. The absence of bounds makes it likely that the IMP form has a naming function (Forsyth 1970$)^{8}$, qualifying

\footnotetext{
${ }^{8}$ In many cases, "the imperfective verb [has a] minimal 'naming' function [; it] is reduced to acting as a kind of link or copula between two important items of information" (Forsyth 1970:84).
} 
the eventuality as a constant, a topic. On the other hand, the presence of telicity asserts that an event has bounds, providing it with a focus-like (i.e. quantificational) character.

\section{Conclusion.}

This chapter has provided an account of some unexpected phenomena involving Russian aspect, in particular the asymmetry between finite and non-finite verbal forms with respect to the construal of viewpoint aspect.

We have claimed that Situation Aspect (SA) and Viewpoint Aspect (VA) do not have the same grammatical status in Russian. Only SA is encoded grammatically; VA is not encoded. A syntactic Telic/QP functional head, associated with lexical prefixes may adjoin in syntax to simple IMP verbal forms to produce PF verbal forms (cf. Borer, 2005). While telic prefixed verbs give rise to Perfective Viewpoint aspect, IMP verbal forms may give rise to either PF or IMP viewpoints. Moreover, the notion of Telicity must be weakened. Only some forms of telicity involve quantification, a relation of simultaneous event-object bounding. The more pertinent notion of Telicity is Terminativity: a telic event is one which is over, whether or not it has a specific lexical boundary.

Since viewpoint aspect is not grammaticalized, it is therefore not surprising that in nonfinite forms, the viewpoint aspect associated with both IMP and PF verbal forms may depend on grammatical subcategorization, conventions of use, or, as shown in the last section, on discourse structure. We suggested a possible link between syntactic structure with/without a Telic functional node and discourse information structure involving Focus and Topic identification during conversational interaction. This last point warrants further research, of course; in particular, one needs to explain the link between modal expressions and the choice of a PF or an IMP infinitive verbs. In relation to that, the phenomenon that is in need of an explanation is the extremely high frequency of association between negatively-oriented modal expressions and IMP aspect. 


\section{References:}

Altshuler, Daniel. 2013. "There is no neutral aspect". Proceedings of Semantics and Linguistic Theory 23, 40-62. Santa Cruz: University of California.

Bondarko, Alexander. 1971. Grammatičeskaja kategorija i kontekst (Grammatical Category and Context). Leningrad: Nauka.

Borer, Hagit. 2005. The Normal Course of Events. Oxford: Oxford University Press.

Corre, Eric. 2015 (to appear). "Preverbs in Russian: situation or viewpoint aspect?" In J. Guéron \& B. Copley (eds.), Constructing Aspect Syntactic Reflections on Aspectual Distinctions - n $43 / 2014$. Recherches Linguistique de Vincennes. Université Paris 8 : P.U.V.

Depraetere, Ilse. 1995. « On the Necessity of Distinguishing between (Un)boundedness and (A) telicity », in Linguistics and Philosophy $\mathrm{n}^{\circ} 18.1-19$.

Dowty, David. 1979. Word Meaning and Montague Grammar. Dordrecht: Reidel.

Filip, Hana. 2000, « The Quantisation Puzzle», in Pustejovsky, J., Tenny, C. (eds), Events as Grammatical Objects, from the Combined Perspectives of Lexical Semantics, Logical Semantics and Syntax, Stanford, CSLI publications. 3-60.

Filip, Hana. 2008. "Events and maximalization: the case of telicity and perfectivity", in Rothstein S. ed. Theoretical and Cross-Linguistic Approaches to the Semantics of Aspect. Amsterdam: benjamins. 257-290.

Forsyth, James. 1970. A Grammar of Aspect. Usage and Meaning in the Russian verb. Cambridge: Cambridge University Press.

Isačenko, Alexander. 1960. Grammatičeskij stroi russkogo jazyka v sopostavlenii $s$ slovackim: morfologija, čast' 2, (The Structure of Russian in Comparison to Slovak: Morphology, Part 2). Bratislava.

Krifka, Manfred. 1998. The origins of telicity. In Rothstein, S. (ed.) Events and Grammar: 197-236. Dordrecht: Kluwer Academic Publishers.

Łakorczyk, Agnieszka. 2010. Decomposing Slavic Aspect: the Role of Aspectual Morphology in Polish and Other Slavic Languages. Dissertation Presented to the Faculty of the USC Graduate School University of Southern California.

Lambrecht, Knut. 1994. Information Structure and Sentence Form. Cambridge: Cambridge University press.

Maslov, Yurii. 1948. Vid i leksičeskoe značenie glagola $\mathrm{v}$ sovremennom russkom literaturnom jazyke (Aspect and the lexical meaning of the verb in contemporary literary Russian). Moscow: Jazyki Slavjanskoj Kul’tury. 71-89. 
Maslov, Yurii. 1972. Sistema vidovyx značenij i tipy protivopostavlenij soveršennogo i nesoveršennogo vida (The system of aspectual meanings and the types of oppositions between the perfective and imperfective aspects). Moscow: Jazyki Slavjanskoj Kul'tury. 96-110.

Mehlig, Hans Robert (2008). Aspect and bounded quantity complements in Russian. In Rothstein, S.(ed). Theoretical and Crosslinguistic Approaches to the Semantics of Aspect: 257-291. Amsterdam/Philadelphia: John Benjamins.

Nuyts, Jan. 2012. Notions of (Inter)Subjectivity. In: Brems, Lieselotte, Lobke Ghesquière and Freek Van de Velde (eds.), Intersections of Intersubjectivity. Special issue of English Text Construction 5:1. 53-76.

Padučeva, Elena. 1996. Semantičeskie issledovanija (Semantic investigations). Moscow: Škola 'Jazyki russkoj kul'tury'.

Padučeva, Elena \& Pentus, Mati (2008). Formal and informal semantics of telicity. In Rothstein, S.(ed). Theoretical and Crosslinguistic Approaches to the Semantics of Aspect: 191-215. Amsterdam/Philadelphia: John Benjamins.

Paillard, Denis. 1979. Voix et aspect en russe contemporain. Paris : Institut d'Etudes Slaves.

Rizzi, Luigi. (1997). «The fine structure of the left periphery », in L. Haegeman (ed.), Elements of Grammar. Dordrecht: Kluwer.

Šmelev, Aleksej\& Zaliznjak, Anna. 1997. Lekcii po russkoj aspektologii (Lessons on Russian aspectology), Slavistische Beiträge; Munich : Verlag Otto Sagner.

Smith, Carlota. 1991. The Parameter of Aspect. The Netherlands: Kluwer Academic Publishers.

Tenny, Carol (1994). Aspectual roles and the syntax-semantics interface. Dordrecht/ Boston: Kluwer Academic Publishers.

Timberlake, Alan. 2004. A Reference Grammar of Russian. Cambridge: C.U.P.

Tournadre, Nicolas. 2004. Typologie des aspects verbaux et intégration à une théorie du TAM. Bulletin de la Société Linguistique de Paris, t. XCIX, fasc. 1, 7-68.

Vendler, Zeno. 1957. Verbs and Times, in Linguistics in Philosophy (1967), Ithaca, New York, Cornell University Press, 97-121.

Veyrenc, Jacques. 1980. Etudes sur le verbe russe; Paris : Institut d' Etudes slaves.

Zucchi, Sandro (1999). Incomplete events, intensionality and imperfective aspect. Natural Language Semantics 7: 179-215. 


\section{1) Chapter abstract:}

The present chapter has two goals. First, it seeks to assess the validity of the Situation Aspect (SA)-Viewpoint Aspect (VA) distinction (Smith 1991) for the aspectual PF/IMP opposition in Russian in finite modes. Second, after presenting the thesis that only SA is grammaticized in Russian through the presence of a syntactic Telic functional head (Borer 2005), it aims at explaining how this constraint extends to aspectual opposition in the infinitive mode in Russian.

The concept of telicity defended here is akin to Paducheva \& Pentus' (2008) terminativity: the function of the preverb is to seal off the event. Following Borer (2005) \& Lakorczyk (2010), the claim is advanced that it suffices for an event to be either non divisive or non homogeneous to be telic.

A corpus study is presented which shows that aspectual opposition in the infinitive modes obeys the same contraints: IMP verbs display a strong tendency to occur in non-telic environments (generalizing, durative, contexts), whereas PF verbs are happy with telic/terminative contexts (single events, and so-called vivid-illustrative contexts). There remain a small proportion of cases in which aspectual opposition in the infinitive is regulated by discourse-interactional parameters: the PF verb or rather, vP) behaves like a Focus, and the IMP verb like a topic in the sense of Rizzi and Lambrecht, thereby providing a link between syntax and discourse: the TelicP is raised to the $\mathrm{CP}$ domain.

\section{2) 5-10 key words :}

Situation aspect, viewpoint aspect, prefixation, telicity, terminativity, discourse interaction, focus, topic, split-CP.

\section{3) Academic biography:}

Eric Corre is Professor of Linguistics in the English Department at the University of Sorbonne Nouvelle Paris 3, where he completed his Dissertation in 2008 and has been a member of the faculty since 2009. His research interests lie in the area of aspect and event structure, with a focus on contrastive linguistics (English, Russian) in the past few years. He has also collaborated with researchers in other languages - Lithuanian, Khmer and Hungarian- in particular in the domain of verbal prefixation and complex predicates.

Most of his publications are concerned with the verb and verbal aspect. His 2009 book, De l'aspect sémantique à la structure de l'événement - Les verbes anglais et russes recapitulated the principle insights of fifteen other publications that ranged from the present perfect in English to verbal prefixation in Russian. 